\title{
PROGRESS REPORT OF FY 1997 ACTIVITIES: The Application of Kalman Filter- ing to Derive Water Vapor Profiles from Combined Ground-Based Sensors: Raman Lidar, Microwave Radiometers,GPS, and Radiosondes
}

Principal Investigators:

Edgeworth R. Westwater Yong Han
CIRES/NOAA/ETL

CIRES/NOAA/ETL

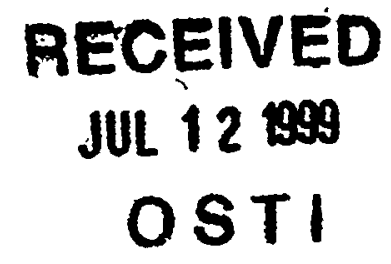

ABSTRACT

Previously, the proposers have delivered to ARM a documented algorithm, that is now applied operationally, and which derives water vapor profiles from combined remote sensor measurements of water vapor radiometers, cloud-base ceilometers, and radio acoustic sounding systems(RASS). With the expanded deployment of a Raman lidar at the CART Central Facility, high quality, high verticalresolution, water vapor profiles will be provided during nighttime clear conditions, and during clear daytime conditions, to somewhat lower altitudes. The object of this proposal was to use Kalman Filtering, previously applied to the combination of nighttime Raman lidar and microwave radiometer data, to derive high-quality water vapor profiles, during non-precipitating conditions, from data routinely available at the CART site. Input data to the algorithm would include: Raman lidar data, highly qualitycontrolled data of integrated moisture from microwave radiometers and GPS, RASS, and radiosondes. The algorithm will include recently-developed quality control procedures for radiometers. The focus of this years activities has been on the intercomparison of data obtained during an intensive operating period at the SGP CART site in central Oklahoma.

\section{PARTICIPATION IN THE WATER VAPOR INTENSIVE OPERATING PERIOD IN 1996.}

To combine data by Kalman filtering, it is necessary to know the error characteristics of aach data source and to eliminate, as far as possible, sources of internal inconsistency between the data. The input data for our Kalman algorithm will be mixing ratio profiles from the ARM Raman lidar, precipitable water vapor (PWV) from the ARM microwave radiometer (MWR) and possibly PWV from the Global Positioning System (GPS) that is operated by the National Weather Service at Lamont, Oklahoma, and Vaisalla type radiosondes that are operated at the Southern Great Plains CART Central Facility. To gather and analyze data relevant to this combination, we participated in the Water Vapor Intensive Operating Period at the SGP Central Facility from September 15 - 30, 1997. As an aid to evaluate the performance of the ARM MWR, we brought to the CART site and operated dual-channel radiometers belonging to the Environmental Technology Laboratory (ETL). The costs of bringing the ETL radiometers to WVIOP'96 were obtained independently of this effort but the analysis of these data was supported by the Kalman filtering project. ETL and Jim Liljegren, the ARM instrument mentor for the MWR, collaborated closely on the analysis. A time series of the PWV data gathered from the experiment is shown in Figure 1. We note that there is generally good agreement between all data, and that there was a substantial range in PWV (from 0.5 to $5.0 \mathrm{~cm}$ ) during this two-week experiment. However, to be useful in combined retrievals, it is believed that accuracies of at least $0.1 \mathrm{~cm} \mathrm{rms} \mathrm{in}$ PWV are required. We therefore spent a substantial amount of time comparing data from the ETL and 


\section{DISCLAIMER}

This report was prepared as an account of work sponsored by an agency of the United States Government. Neither the United States Government nor any agency thereof, nor any of their employees, make any warranty, express or implied, or assumes any legal liability or responsibility for the accuracy, completeness, or usefulness of any information, apparatus, product, or process disclosed, or represents that its use would not infringe privately owned rights. Reference herein to any specific commercial product, process, or service by trade name, trademark, manufacturer, or otherwise does not necessarily constitute or imply its endorsement, recommendation, or favoring by the United States Government or any agency thereof. The views and opinions of authors expressed herein do not necessarily state or reflect those of the United States Government or any agency thereof. 


\section{DISCLAIMER}

Portions of this document may be illegible in electronic image products. Images are produced from the best available original document. 
ARM radiometers, the NWS GPS system, and the Balloon Borne Sounding System (Vaisalla ) radiosondes. Part of the experimental procedure was to randomly deploy radiosondes from different calibration lots and examine the differences, if any, between the two data lots. Another important classification was that of remote sensor performance between clear and cloudy (non-precipitating) conditions. We determined clear conditions in two ways: the first, by far the most stringent, was to use the Raman lidar aerosol channel to determine clear; the second, was to examine the variance of the cloud sensitive channel $(31.4 \mathrm{GHz})$ of the ARM radiometer. Results of these analyses are outlined below and summarized in Table 1.

ARM vs. ETL microwave radiometers for determination of PWV.

It was obvious from casual inspection that the data from the two radiometers were highly correlated, even during cloudy conditions. An detailed analysis of the data showed agreement of 0.08 $\mathrm{cm} \mathrm{rms} \mathrm{during} \mathrm{clear} \mathrm{and} 0.09 \mathrm{~cm}$ rms during cloudy conditions. What was particulary promising was that a dependent sample regression analysis, carried out over 11137 points, yielded an error of $0.02 \mathrm{~cm}$ rms. The results demonstrate that ARM MWR data can be used in Kalman filtering algorithms during non-precipitating conditions.

ARM and ETL microwave radiometers vs. GPS for determination of PWV.

Data from both ARM and ETL radiometers did not agree as closely with the GPS as they did with each other with rms differences of 0.12 and $0.16 \mathrm{~cm}$ rms during clear and cloudy. However, at the very least, the GPS could serve as an effective quality control on the ARM MWR, which is subject to problems during and immediately after precipitation.

ARM and ETL microwave radiometers vs. BBSS radiosondes

As had been pointed out earlier by Liljegren and Lesht, the calibration of Vaisalla radiosondes used at CART depended on the particular lot in which the sondes were calibrated. During the 96 IOP, these differences gave rise to a bias of $0.15 \mathrm{~cm}$ between the two calibration lots. It is thus highly suggestive that ARM MWR data could be used to normalize data between different lots.

\section{PLANS FOR FY 1998}

- Using the quality controlled data base obtained during wviop'96, extend the analysis to include the ARM Raman lidar, which was operating throughout the duration of the iop. The analysis will focus initially on the PWV comparisons during clear and nightime conditions.

- To develop the error covariance matrices and transition matrices that are required for the Kalman filter algorithm from a subset of the wviop' 96 data and apply the algorithm to independent data taken from SGP instruments.

- Deliver a Kalman filter algorithm to ARM

- To publish the results of wviop-96 in an open literature publication

- To participate in wviop'97. 


\section{PAPERS PUBLISHED OR SUBMITTED AFTER OCTOBER 1, 1996}

1. Y. Han and E. R. Westwater (1997): Applications of Kalman Filtering to Derive Water Vapor from Raman Lidar and Microwave Radiometers. J. Atmos. Oceanic Technol., 14, Part 1, June, 481-487.

2. Westwater, E. R. , 1997: Remote sensing of tropospheric temperature and moisture by integrated observing systems. Bull. Amer. Meteor. Soc.,78, 1991-2006. 


\begin{tabular}{|c|c|c|c|c|c|c||}
\hline \multicolumn{6}{|c|}{ TABLE 1. COMPARISON OF PWV MEASUREMENTS DURING WVIOP'96 } \\
\hline \hline $\begin{array}{c}\text { Intercept } \\
(\mathrm{cm})\end{array}$ & Slope & $\begin{array}{c}\text { Dispersion } \\
(\mathrm{cm})\end{array}$ & $\begin{array}{c}\text { rms } \\
(\mathrm{cm})\end{array}$ & $\begin{array}{c}\text { bias } \\
\text { (cm) }\end{array}$ & sample size \\
ETL (all) & 0.104 & 0.932 & 0.026 & 0.094 & -0.071 & 11137 \\
\hline $\begin{array}{c}\text { ARM vs. } \\
\text { ETL(clear) }\end{array}$ & 0.098 & 0.936 & 0.020 & 0.081 & -0.058 & 7753 \\
\hline $\begin{array}{c}\text { GPS vs. } \\
\text { ARM }\end{array}$ & 0.033 & 1.023 & 0.084 & 0.152 & 0.093 & 755 \\
\hline $\begin{array}{c}\text { BBSS (lot } \\
\text { 62) vs. } \\
\text { ARM }\end{array}$ & 0.397 & 0.913 & 0.103 & 0.232 & 0.169 & 44 \\
\hline $\begin{array}{c}\text { BBSS (lot } \\
\text { 63) vs. } \\
\text { ARM }\end{array}$ & 0.092 & 0.967 & 0.078 & 0.112 & 0.009 & 76 \\
\hline \hline
\end{tabular}


Figure 1. Time series of PWV measurements during WVIOP'96 
October 2, 1997

\author{
Dr. Patrick A. Crowley \\ Arm Science Director, \\ Atmospheric Radiation Measurement Program \\ Environmental Sciences Division, ER-74 \\ Office of Health and Environmental Research \\ Office of Energy Research
}

U. S. Department of Energy

19901 Germantown Road

Germantown, Maryland 20874

Dear Dr. Crowley

Enclosed is the progress report for FY 1997 on our DOE/ARM project (ARM Grant ER62343), entitled "The Application of Kalman Filtering to Derive Water Vapor Profiles from Combined Ground-Based Sensors: Raman Lidar, Microwave Radiometers, GPS, and Radiosondes" by Ed R. Westwater and Yong Han. The funds on this project have been expended. In the results section, I have highlighted in boldface, the principal conclusions reached from this years study. Any questions concerning either the scientific or the administrative portions of the contract should be directed to me.

Sincerely,

Ed R. Westwater

Research Physicist

Ocean Remote Sensing Division

Environmental Technology Laboratory

ph: $303-497-6527$

FAX: 303-497-3577

email: ewestwater@etl.noaa.gov 